I997

Fall

I997

Automne
Papers of the

Bibliographical Society

of Canada

Cahiers de la

Société bibliographique

du Canada

Volume $35, \# 2$

The Bibliographical Society of Canada La Société bibliographique du Canada Toronto, Canada I997 
$\infty$

Printed on acid-free paper.

Imprimé sur papier sans acide.

ISSN $0067-6896$ 


\section{Table of Contents / Table des matières}

'Dragged at Anne's Chariot Wheels':

L.M. Montgomery and the Sequels to Anne of Green Gables CAROLE GERSON

Beyond the Shadow of William Briggs, Part II:

Canadian-Authored Titles and the Commitment to Canadian Writing

JANET FRISKNEY

Books in Review / Comptes rendus

MICHEL BRISEBOIS and / et FRANÇOIS MELANÇON

Alberto Manguel, A History of Reading (Gillian Fenwick), p. 209; Roger C. Lewis, Thomas James Wise and the Trial Book Fallacy (Bruce Whiteman), p. 2 I4; Jacques Michon, dir., Éditions et pouvoirs (Martin Pâquet), p. 21 5; David Skene-Melvin, comp., Canadian Crime Fiction: An Annotated Comprehensive Bibliography of Canadian Crime Fiction from I 817 to 1996 and Biographical Dictionary of Canadian Crime Writers . . (Allan Weiss), p. 218; Carl Morey, Music in Canada: A Research and Information Guide (Maria Calderisi Bryce). p. 220; Gerard Long, ed., Books Beyond the Pale: Aspects of the Provincial Book Trade in Ireland Before I 850 (Patrick McGahern), p. 222; Michael S. Macrakis, ed., Greek Letters: From Tablets to Pixels (Bruce Whiteman), p. 224.

Brief Notices / Notices abrégées

Jesús R. Anaya Rosique, ed., Jack McClelland: The Publisher of Canadian Literature / el editor de la literatura canadiense, p. 227; Mel Hurtig, At Twilight in the Century: Memoirs of a Canadian Nationalist, p. 228; Karen Smith, Vessels of Light: A Guide to Special Collections in the Killam Library Dalhousie University Libraries, p. 229; Gilles Lapointe, L'envol des signes. Borduas et ses lettres, p. 230; D.C. Greetham, ed., Scholarly Editing: A Guide to Research, p. 23 i; S.H. Steinberg, Five Hundred Years of Printing, p. 232; David Woodward, Catalogue of Watermarks in Italian Printed Maps, ca I 540-I600, p. 233; Harry M. Solomon, 
The Rise of Robert Dodsley: Creating the New Age of Print, p. 234; F. Blom, J. Blom, F. Korsten, and G. Scott, comps., English Catholic Books I70I-I 800: A Bibliography, p. 235; Frederick G. Ribble and Anne G. Ribble, Fielding's Library: An Annotated Catalogue, p. 236; Leona Rostenberg and Madeleine B. Stern, Old Books in the Old World: Reminiscences of Book Buying Abroad, p. 236; Colin Franklin, Book Collecting as One of the Fine Arts and Other Essays, p. 237. 